\title{
Membangun Kemandirian Industri Benih Padi Nasional
}

\author{
Bambang Sayaka $^{\mathrm{a}, *}$, Frans B. M. Dabukke ${ }^{\mathrm{b}}, \&$ Sri Suharyono $^{\mathrm{c}}$ \\ ${ }^{a}$ Peneliti Ahli Utama pada Pusat Sosial Ekonomi dan Kebijakan Pertanian, Kementerian Pertanian \\ ${ }^{b}$ Peneliti Ahli Muda pada Pusat Sosial Ekonomi dan Kebijakan Pertanian, Kementerian Pertanian \\ ${ }^{c}$ Penganalisis Data pada Pusat Sosial Ekonomi dan Kebijakan Pertanian, Kementerian Pertanian
}

\begin{abstract}
The high quality rice seed supply of improved variety has not been able to fulfill the rice farmers' demand. The objective of the study is to formulate policy recommendation to empower rice seed growers such that rice farmers reach seed self-reliance. This study was conducted using a survey approach in six provinces. Primary data were analyzed using a farm business cost and income approach. The results suggest that seed policy since the implementation of regional autonomy has changed as market develops. Rice seed production and distribution is relatively well managed by the government. Rice seed growers tend to choose high-yielding variety according to market demand. Rice farmers will adopt quality rice seed of improved variety as long as it is high yielding, resistant to pest and disease attack, easily accessed, and affordable.
\end{abstract}

Keywords: rice; seed; growers; seed system; quality

\begin{abstract}
Abstrak
Secara umum, pasokan benih padi bermutu dari varietas unggul belum memenuhi kebutuhan petani padi. Tujuan penelitian adalah merumuskan rekomendasi kebijakan untuk pemberdayaan penangkar benih dalam upaya mendukung kemandirian benih padi. Penelitian dilaksanakan dengan metode survei di enam provinsi. Data primer diolah menggunakan pendekatan biaya dan pendapatan usahatani. Kebijakan perbenihan berubah dalam era otonomi sesuai perkembangan pasar. Produksi dan peredaran benih padi relatif diawasi dengan baik. Penangkar benih padi cenderung memilih varietas berdaya hasil tinggi sesuai permintaan pasar. Petani padi bersedia untuk mengadopsi benih bermutu dari varietas unggul adalah produktivitas tinggi, tahan serangan hama dan penyakit, mudah diakses, dan harga terjangkau.
\end{abstract}

Kata Kunci: padi; benih; penangkar; sistem perbenihan; kualitas Kode Klasifikasi JEL: D04

*Alamat Korespondensi Penulis: Pusat Sosial Ekonomi dan Kebijakan Pertanian Jl. Tentara Pelajar No. 3-B Cimanggu, Bogor 16111, Jawa Barat. E-mail: bambangsayaka@gmail.com. 


\section{Pendahuluan}

Produksi benih tanaman pangan saat ini, termasuk benih padi, merupakan industri tersendiri yang tidak terpisahkan dari sistem budidayanya. Badan Penelitian dan Pengembangan Pertanian (Balitbangtan), Kementerian Pertanian, merupakan salah satu lembaga penyumbang terbanyak varietas baru untuk tanaman padi. Disamping itu lembaga lain seperti Perguruan Tinggi, perusahaan swasta nasional, dan perusahaan swasta multinasional menghasilkan varietas padi. Manfaat dari suatu varietas akan dirasakan oleh petani apabila benihnya tersedia dalam jumlah yang cukup dengan harga yang sesuai. Dalam pertanian modern, benih berperan sebagai delivery mechanism yang menyalurkan keunggulan teknologi kepada clients, yaitu petani (Douglas, 1980). Menghasilkan varietas unggul, memproduksi benih unggul, dan menyalurkannya hingga ke petani memerlukan sistem perbenihan formal yang efisien dan efektif agar diperoleh manfaat yang optimal (Singh \& Agrawal, 2018; Sperling et al., 2013). Sebaliknya, penyebaran varietas unggul dalam sistem benih informal berlangsung lebih lambat. Petani maupun penangkar dalam sistem benih informal tidak mengikuti peraturan sertifikasi benih. Penggunaan benih sendiri atau membeli benih tanpa sertifikat biasa dijumpai dalam sistem benih informal. Walaupun demikian benih yang mereka gunakan tidak selalu berkualitas buruk. Pembinaan oleh pemerintah diperlukan agar petani maupun penangkar dalam sistem benih informal dapat meningkatkan kualitas benih yang digunakan maupun bersedia mengadopsi benih unggul (Paturohman \& Sumarno, 2017; El Khoury \& Delve, 2018).

Dalam rangka revitalisasi perbenihan, Kementerian Pertanian (2010) mencanangkan kegiatan sebagai berikut: (1) Menata kembali kelembagaan perbenihan/perbibitan nasional mulai dari tingkat pusat sampai daerah; (2) Melindungi, memelihara dan memanfaatkan sumberdaya genetik nasional untuk pengembangan varietas unggul lokal; (3) Memperkuat tenaga pemulia dan pengawas benih tanaman; (4) Memberdayakan penangkar dan produsen benih berbasis lokal; (5) Meningkatkan peran swasta dalam membangun industri perbenihan/perbibitan; dan (6) Membangun industri perbenihan dengan arah sebagai berikut: (i) Kemandirian industri benih nasional yang mencakup kemandirian produksi benih dan industri varietas; (ii) Kemandirian penyediaan benih berbasis kawasan; (iii) Industri benih berbasis komunitas; dan (iv) Riset berbasis perbenihan.

Beberapa permasalahan yang terkait dengan kinerja sistem dan kelembagaan benih (Nurmanaf et. al., 2003), antara lain: (i) struktur industri dan produksi benih di nilai tidak kondusif dalam menciptakan sistem usaha dan pasar yang sehat, (ii) konsekuensinya adalah tingkat harga yang tinggi sehingga tidak terjangkau oleh sebagian besar petani yang direfleksikan oleh tingkat partisipasi dan penggunaan benih berkualitas (berlabel) yang sangat rendah, (iii) efektivitas sistem distribusi yang lemah karena benih tidak selalu tersedia dipasaran saat petani membutuhkan, (iv) tidak tersedianya benih di lapangan karena resiko pemasaran yang tinggi sepenuhnya ditanggung oleh pengecer, dan (v) faktor 
eksternal yang ikut berpengaruh terhadap ketersediaan dan penggunaan benih, adalah masih relatif rendahnya tingkat efisiensi dan diversifikasi industri benih serta kinerja ekonomi perberasan yang kurang kondusif bagi pemanfaatan benih berkualitas.

Benih varietas unggul dan bermutu merupakan kebutuhan pokok bagi petani untuk mencapai produktivitas yang tinggi. Adopsi benih varietas unggul untuk padi sudah cukup luas. Walaupun demikian masih banyak petani yang menggunakan benih tidak bersertifikat. Hasil penelitian Ruskandar et al. (2007) menunjukkan bahwa adopsi benih unggul bersertifikat di Jawa Barat, Jawa Tengah, Yogyakarta, dan Jawa Timur masing-masing 59,3 persen, 64,7 persen, 72,5 persen, dan 99,2 persen. Pada tahun 2012 adopsi benih padi varietas unggul baru (VUB) bersertifikat secara nasional sebesar 61,6 persen (179.602 ton) (Direktorat Perbenihan, 2014). Masih ada sebagian petani menggunakan benih yang dihasilkan sendiri dengan cara memilih hasil panen yangbaik. Benih yang digunakan petani walaupun merupakan varietas unggul pada taraf tertentu tidak terjamin kualitasnya (Baglan et al., 2020; Bishaw et al., 2012).

Melalui Program Model Kawasan Mandiri Benih (MKMB), Badan Litbang Pertanian (2015), Kementerian Pertanian ingin memberdayakan kelompok penangkar benih padi agar dapat menghasilkan benih berkualitas. Dalam hal ini kelompok penangkar benih, jika dibimbing dan difasilitasi, akan dapat berpartisipasi dalam meningkatkan volume produksi benih unggul bersertifikat untuk memenuhi kebutuhan benih petani. Kelompok penangkar non-formal benih padi akan ditingkatkan menjadi penangkar formal atau bahkan menjadi produsen benih. Walaupun demikian, banyak masalah selain faktor teknis dalam pengembangan kelembagaan penangkar benih padi. Ketersediaan modal dan jaminan pasar merupakan faktor penghambat pengembangan penangkar benih padi yang umumnya merupakan petani berskala kecil. Pembinaan dan pengawasan mutu benih selama proses produksi dan pemasaran dilakukan oleh BPSBTPH (Balai Sertifikasi dan Pengawasan Benih Tanaman Pangan dan Hortikultura) yang ada di tiap provinsi melalui penerapan prinsip-prinsip sertifikasi benih berbasis OECD Schemefor the VarietalCertification (Nugraha et al., 2014). Sesuai peraturan, produsen benih juga dapat memproduksi benih tanpa harus mendapat sertifikasi dari BPSB dengan catatan memperoleh Sertifikasi Sistem Manajemen Mutu yang diselenggarakan oleh Lembaga Sertifikasi Sistem Mutu (LSSM) yang terakreditasi oleh lembaga akreditasi sesuai ruang lingkup di bidang perbenihan (Kementerian Hukum dan Hak Asasi Manusia, 2014).

Tujuan umum penelitian ini adalah merumuskan rekomendasi kebijakan pemberdayaan penangkar benih dalam upaya mendukung kemandirian benih padi. Secara khusus tujuan kajian ini adalah untuk: (i) Menganalisis kebijakan perbenihan dan peran penangkar benih padi sebelum dan sesudah era otonomi; (ii) Mengkaji efektivitas mekanisme kontrol mutu dan penyaluran benih padi; dan (iii) Mengkaji faktor-faktor yang mempengaruhi tingkat adopsi teknologi produksi benih padi oleh penangkar dan adopsi benih bermutu oleh petani. 


\section{Metodologi}

Pada dasarnya produksi benih padi bermutu menggunakan varietas unggul di Indonesia cukup menjanjikan mengingat semakin banyak petani padi mengadopsi varietas unggul. Walaupun demikian beberapa daerah produksi padi dimana produksi dan distribusi benih padi bermutu dari varietas unggul belum berkembang banyak dijumpai petani menggunakan benih buatan sendiri yang kualitasnya di bawah standar BPSBTPH. Bhakan banyak petani padi melakukan barter gabah yang dimiliki dengan gabah milk petani lain yang berasal dari varietas unggul. Kementerian Pertanian melalui Balitbangtan melaksanakan program Model Kawasan Mandiri Benih (MKMB) agar petani mampu menjadi penangkar benih yang memproduksi benih bermutu menggunakan varietas unggul untuk digunakan oleh kelompoknya atau dijual secara komersial.

Penelitian ini dilaksanakan dengan metode survei pada program pemberdayaan penangkar benih oleh Balitbangtan, yaitu Model Kawasan Mandiri Benih (MKMB), khususnya benih padi yang dibina oleh Balai Pengkajian Teknologi Pertanian (BPTP) pada Januari-Desember 2015. Lokasi penelitian meliputi tujuh kabupaten di enam provinsi, yaitu Kabupaten Sumbawa (Nusa Tenggara Barat), Kabupaten Maros (Sulawesi Selatan), Kabupaten Tapin (Kalimantan Selatan), Kabupaten Lampung Selatan (Lampung), Kabupaten Garut dan Kabupaten Majalengka (Jawa Barat), serta Kabupaten Tulungagung (Jawa Timur). Makalah ini diperbarui dengan data sekunder berupa informasi kualitatif dari laporan tentang kegiatan Sekolah Lapang MKMB yang dilakukan oleh Pusat Penelitian dan Pengembangan Tanaman Pangan, Balitbangtan (Widiarta, 2017,2018,2019).

Responden survei meliputi berbagai pihak yang terlibat dalam Program MKMB sebanyak 91 orang. Secara rinci data primer dikumpulkan melalui wawancara dengan responden menggunakan kuesioner terstruktur, yaitu kelompok petani pengkar benih padi (29 orang), petani padi (16 orang), produsen benih (12 orang), pedagang benih (6 orang), penanggung jawab kegiatan di BPTP (9 orang), Pengamat Benih Tanaman (PBT) di BPSBTPH (8 orang), staf Balai Benih Induk atau BBI (7 orang), dan staf Dinas Pertanian Kabupaten (6 orang). Data sekunder dikumpulkan melalui publikasi maupun laporan dari instansi terkait.

Metode untuk menganalisis kebijakan perbenihan dan peran penangkar sebelum dan sesudah era otonomi dilakukan dengan membandingkan sistem perbenihan dalam kedua era tersebut. Keuntungan penangkar benih padi dihitung dengan rumus sebagai berikut:

$$
\pi=T P-T B
$$

dimana $\pi=$ keuntungan penangkar benih ( $\mathrm{Rp} /$ hektar); $\mathrm{TP}=$ total pendapatan (Rp/hektar) yang merupakan perkalian volume calon benih padi yang dihasilkan oleh penangkar $(\mathrm{kg} /$ hektar) dengan harga benih $(\mathrm{Rp} / \mathrm{kg})$; TB = total biaya (Rp/hektar) yang merupakan penjumlahan dari biaya sarana produksi (benih sumber, pupuk, pestisida, tenaga kerja).

Analisis efektivitas kontrol mutu dan penyaluran benih padi dilakukan secara 
deskriptif melalui wawancara dengan penangkar benih, petugas BPSBTPH dan pedagang benih padi. Sedangkan faktor-faktor yang memengaruhi tingkat adopsi teknologi produksi benih padi oleh penangkar dan adopsi benih bermutu oleh petani dianalisis secara deskriptif melalui wawancara dengan penangkar benih dan petani padi serta pengamatan di lapang.

\section{Hasil dan Pembahasan}

\subsection{Kebijakan Perbenihan dan Peran Penangkar dalam Sistem Perbenihan Sebelum dan Sesudah Era Otonomi}

Inisiasi industri benih di Indonesia di mulai pada 1971 dengan penerbitan beberapa peraturan dan keputusan terkait kebijakan perbenihan, seperti Peraturan Pemerintah No. 22 tahun 1971 tentang pendirian Perum Sang Hyang Seri, Keputusan Presiden RI No. 27 tahun 1971 tentang Badan Benih Nasional Surat Keputusan Menteri Pertanian No. 174 tentang pembentukan Dinas Pengawasan dan Sertifikat Benih, Surat Keputusan Menteri Pertanian No.183 tentang pembentukan Lembaga Pusat Penelitian Pertanian Cabang Sukamandi. Semua aktivitas tersebut secara sinergis mendukung program intensifikasi padi (BIMAS), yang akhirnya mampu memberikan kontribusi substansial terhadap peningkatan produksi padi nasional dengan tercapainya swasembada beras pada tahun 1984 (Nugraha, 2004).

Landasan hukum tentang perbenihan antara lain Keputusan Presiden No. 72 Tahun 1971 tentang Pembinaan Pengawasan Pemasaran dan Sertifikasi Benih, yang kemudian diperkuat dengan peraturan-peraturanyang lebih mutakhir seperti Undang-Undang No. 12/1992 tentang Sistem Budi Daya Tanaman dan Peraturan Pemerintah No. 44/1995 tentang Perbenihan Tanaman (Badan Benih Nasional [BBN], 2004). Untuk memfasilitasi pembinaan dan pengawasan dalam produksi benih bermutu, lembaga-lembaga yang terlibat dalam produksi, distribusi dan pengawasan mutu benih kelas BS (breeder seed), FS (foundation seed), SS (stock seed), dan secara formal telah ditetapkan seperti pada Gambar 2. Pembinaan dan pengawasan mutu benih selama proses produksi dan pemasaran dilakukan oleh BPSB (Balai Pengawasan dan Sertifikasi Benih) yang ada di tiap provinsi melalui penerapan prinsip-prinsip sertifikasi benih berbasis OECD Schemefor the Varietal Certification (Nugraha et al., 2014).

Selama ini sistem perbenihan dan sertifikasi benih padi nasional relatif sudah tertata dengan baik, dimana alur benih mulai dari Benih Penjenis (BS) menjadi Benih Dasar (BD), diperbanyak menjadi Benih Pokok (BP) dan akhirnya diperbanyak lagi dan didistrubusikan sebagai Benih Sebar (BR) yang siap oleh ditanam petani. BS adalah benih yang diproduksi oleh dan dibawah pengawasan pemulia tanaman padi dan instansinya yang dalam hal ini adalah Balai Besar Penelitian Padi (BB Padi), Sukamandi. Benih penjenis merupakan sumber perbanyakan benih dasar (BD). BD adalah benih turunan pertama dari BS, yang dalam proses produksinya masih dalam pengawasan agar terjaga kemurniannya. Pada kondisi 
tertentu BD dapat langsung dijadikan benih sebar (BR). BP adalah benih turunan dari $\mathrm{BS}$ dan $\mathrm{BD}$, yang dalam proses produksinya masih dalam pengawasan agar terjaga kemurniannya. BP merupakan sumber perbanyakan BR. BR adalah benih turunan pertama dari BS, BD, dan BP dalam yang proses produksinya masih dalam pengawasan agar terjaga kemurniannya. Warna label BS, BD, BP, dan BR masing-masing adalah kuning, putih, ungu, dan biru.

Berikut adalah uraian tentang sistem pengadaan dan penyaluran benih pada era sentralisasi atau sebelum otonomi daerah. Varietas unggul yang baru dilepas berupa benih penjenis (BS) yang dihasilkan oleh Puslitbang/Balai Komoditas diteruskan oleh Direktorat Benih untuk disebarkan ke Balai Benih Induk (BBI) yang selanjutnya diperbanyak untuk menghasilkan benih dasar (BD). Benih BD tersebut kemudian diperbanyak oleh BUMN (PT SHS dan PT Pertani), Penangkar Swasta, dan Balai Benih Utama (BBU) yang masing-masing memproduksi benih pokok (BP) atau benih sebar (BR). Kecuali di BBU, benih jenis BP tersebut selanjutnya diperbanyak menjadi benih jenis BR (Gambar 1).

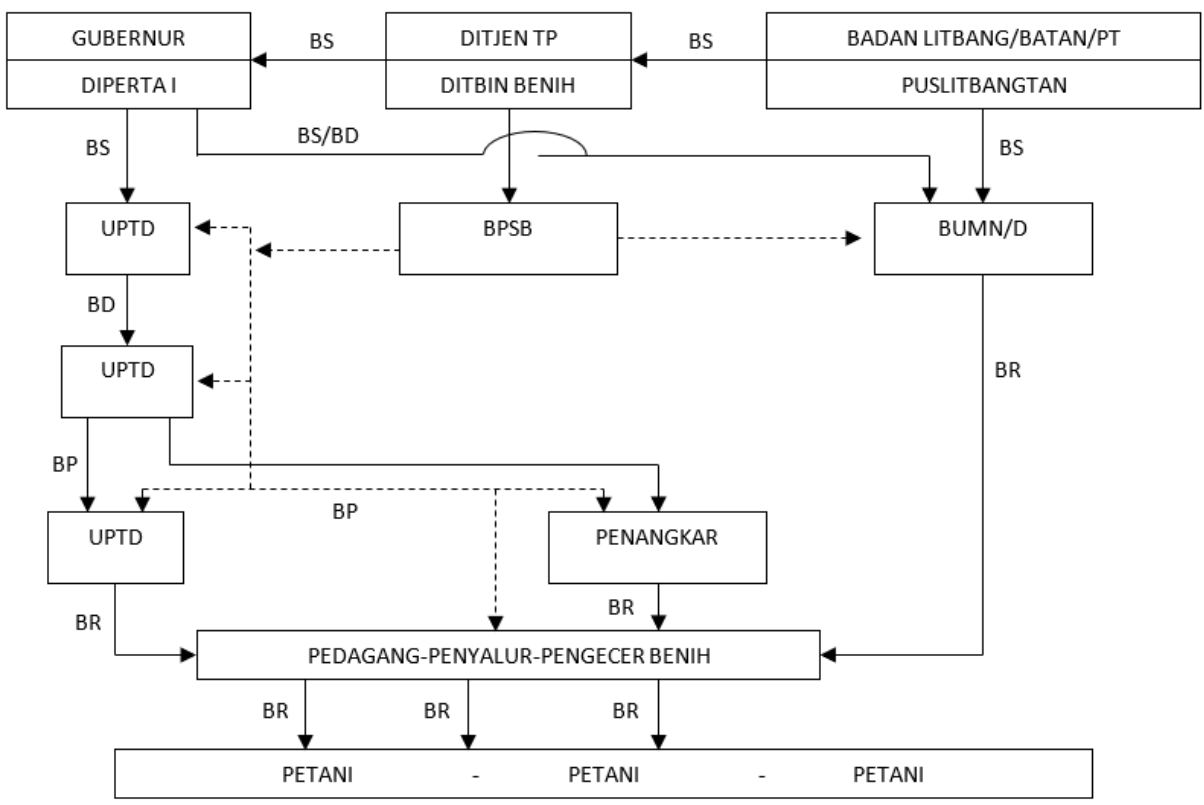

Gambar 1: Sistem Penyaluran Benih secara Formal Sebelum Era Otonomi Daerah Sumber: Bastari (1995) dan Soemardhi (1987)

Dari penangkar swasta benih jenis BR ini langsung disebarkan ke petani, sedangkan dari PT SHS dan PT Pertani disebarkan ke daerah melalui penyalur yang telah ditunjuk. Sementara dari BBU benih BP diteruskan ke BPP, di beberapa wilayah sudah satu atap dengan Dinas Pertanian Kabupaten. Di tingkat $\mathrm{BPP}$, benih jenis BP ini diperbanyak menjadi benih jenis BR yang selanjutnya 
diteruskan kepada petani (Bastari, 1995; Soemardhi, 1987).

Sangat jarang produsen benih padi skala besar yang memperbanyak benih tanpa bermitra dengan petani penangkar. Keuntungan produsen benih bermitra dengan penangkar antara lain membutuhkan modal lebih sedikit untuk sewa lahan dan membayar tenaga kerja. Umumnya produsen memberi pinjaman benih sumber, pupuk dan pestisida kepada penangkar. Keuntungan lainnya yang diperoleh produsen benih adalah membagi risiko dengan penangkar jika terjadi kegagalan panen. Kerugian produsen benih jika melakukan kemitraan adalah berkurangnya keuntungan karena sebagian harus dibagi dengan penangkar (Fitri et al., 2018; Sayaka \& Hidayat, 2015; Ulpah et al., 2018).

Sejalan dengan pelaksanaan otonomi daerah, beberapa lembaga perbenihan tidak lagi dibawah kendali pusat tetapi menjadi institusi daerah pada tingkat provinsi dan kabupaten. Ikatan diantara lembaga perbenihan tersebut makin menjadi kendor. Pada sisi lain meningkatkanya pengaruh pasar bebas dan berkembangnya kebebasan berusaha menyebabkan tumbuhnya sektor swasta termasuk petani mandiri untuk berusaha dibidang perbenihan, termasuk impor benih. Sejalan dengan itu sistem perbenihan semakin kompleks dan tidak lagi mengikuti aturan sistem perbenihan baku sebelumnya (Gambar 2).

Sistem perbenihan padi yang berkembang saat ini melibatkan banyak pelaku yang terlibat. Penghasil VUB bukan hanya Balai Besar Penelitian Padi (BB Padi), tetapi juga Universitas, BATAN, dan LIPI, serta swasta. Di samping itu ada benih impor khususnya benih padi hibrida. Dengan benyaknya pelaku yang terlibat, BS yang dihasilkan oleh BB Padi tidak lagi hanya dijual kepada lembaga tertentu seperti BUMN dan intansi BBI saja tetapi juga memungkinkan dijual kepada pihak produsen benih swasta lainnya. Hal ini dimungkinkan karena disamping tidak ada larangan menjual BS kepada pihak tertentu, juga bisnis perbenihan ini dinilai menguntungkan. Produsen perbenihan yang bergerak dalam penyediaan BD dan BP adalah PT SHS, UPT perbenihan provinsi, UPT perbenihan kabupaten kota, BPTP, swasta, kelompok tani di samping Universitas, BATAN, LIPI, dan Koperasi BB padi. Sementara yang memproduksi BR adalah Perum SHS, swasta, dan kelompok penangkar, serta beberapa UPT perbenihan kabupaten/kota.

Sisi positif dari berkembangnya usaha perbenihan ini berkaitan dengan meningkatkan pasokan dan persaingan penyediaan benih, terutama untuk BD dan BP. Namun dengan banyaknya pelaku telah meningkatkan persaingan diantara pelaku terutama BD, BP, dan BR. Kelebihan pasokan dapat berakibat penggunaan benih diturunkan pada tingkatan yang di bawahnya, misalnya BP menjadi BR dan bahkan menjadi gabah untuk konsumsi.

Prinsip dalam perdagangan benih adalah benih harus diberi label terlebih dahulu sebelum diedarkan sesuai dengan peraturan yang tertulis pada ayat 3 pasal 13 UU No. 12/1992 tentang Sistem Budidaya Tanaman. Benih yang lulus sertifikasi apabila akan diedarkan wajib diberi label. Label benih adalah keterangan tertulis yang dicantumkan pada benih yang sudah dikemas yang akan diedarkan. Isi label benih antara lain keterangan tempat asal benih, jenis dan varietas tanaman, kelas benih (untuk benih yang ada kelasnya), data hasil uji 
laboratorium, serta akhir masa edar benih (pasal 38 PP 44/1995 tentang Pembenihan Tanaman). Cara peredaran benih sudah direvisi berdasarkan Keputusan Mahkamah Konstitusi 2012 tentang peredaran benih bina.

Sistem perbenihan tanaman pangan, khususnya padi, berubah setelah era otonomi daerah. Produsen benih padi dapat membeli benih kelas BS langsung ke Balai Besar Penelitian Padi (BB Padi) di Sukamandi, Kabupaten Subang, Jawa Barat. Produsen benih padi dapat menghasilkan kelas benih BD dan BP tanpa harus membeli dari BBI dan BBU. Disamping itu juga terjadi perubahan internal di dalam Kementerian Pertanian, yaitu BPSBTPH yang semula merupakan lembaga pusat diubah menjadi Unit Pelaksana Teknis Daerah (UPTD) tingkat provinsi (Ilyas et al., 2008).

Dalam Permentan No. 39/2006 (pasal 37 ayat 1) disebutkan bahwa benih bina yang telah lulus sertifikasi dan akan diedarkan, wajib diberi label bertuliskan "BENIH BERSERTIFIKAT" dalam bahasa Indonesia pada kemasan yang mudah dilihat dan tidak mudah rusak. Peraturan ini secara lebih jelas diganti Permentan No. 2/2014 tentang produksi, sertifikasi, dan peredaran benih bina yang pada dengan ayat 1 Pasal 27 disebutkan bahwa benih bina yang diedarkan wajib berlabel. Benih bina merupakan benih varietas unggul yang telah dilepas, yang produksi dan peredarannya diawasi. Permentan No. 8/2015 mengatur bahwa produsen benih harus memiliki ijin yang diterbitkan oleh bupati/walikota.

Permentan No. 2/2014 secara implisit merespon Keputusan Mahkamah Konstitusi 2012 tentang peredaran benih bina. Dalam hal ini petani kecil yang mengedarkan benih untuk kalangan terbatas atau petani sekitarnya tidak diwajibkan harus memberi label pada benih yang dijual. Hal ini mempermudah petani memproduksi benih untuk keperluan sendiri atau untuk kebutuhan petani lain di sekitarnya tanpa mengikuti prosedur formal yang sering menghambat adopsi benih unggul. Di setiap desa atau desa terdekat tempat program MKMB selalu dijumpai toko sarana produksi yang menjual benih bersertifikat dan saran produksi lainnya.

Pasal 13 ayat 2 UU 12/1992 menyatakan bahwa benih bina yang akan diedarkan harus melalui sertifikasi dan memenuhi standar mutu yang ditetapkan oleh Pemerintah. Sertifikasi benih dilakukan oleh BPSBTPH. Produsen benih juga dapat melakukan sertifikasi sendiri jika sudah mendapat pengakuan dari Lembaga Sertifikasi dan Mutu Benih (LSMB). Umumnya produsen benih yang sudah memperoleh pengakuan LSMB adalah produsen besar skala nasional maupun internasional.

Dalam pasal 33 PP 44/1995 dinyatakan bahwa untuk memenuhi standar mutu yang ditetapkan, produksi benih bina harus melalui sertifikasi yang meliputi: (a) Pemeriksaan terhadap: (i) kebenaran benih sumber atau pohon induk; (ii) lapangan dan pertanaman; (iii) isolasi tanaman agar tidak terjadi persilangan liar; (iv) alat panen dan pengolahan benih; dan (v) tercampurnya benih; (b) pengujian laboratorium untuk menguji mutu benih yang meliputi mutu genetis, fisiologis dan fisik; dan (c) pengawasan pemasangan label.

Sertifikasi benih bina diatur dalam pasal 15 ayat 1 Permentan 2/2014, yaitu: 
(i) Untuk memproduksi Benih Bina mengikuti prosedur baku Sertifikasi Benih Bina atau sistem standardisasi nasional; dan (ii) Proses Sertifikasi Benih Bina sebagaimana dimaksud pada ayat (1) meliputi: (a) Pemeriksaan terhadap kebenaran Benih Sumber; lapangan dan pertanaman; isolasi tanaman agar tidak terjadi persilangan liar; alat panen benih; tercampurnya benih; (b) Pengujian laboratorium untuk menguji mutu benih yang terdiri atas mutu fisik, fisiologis, dan/atau tanpa kesehatan benih, sedangkan untuk kemurnian genetik diambilkan dari hasil pemeriksaan lapangan; dan (c) Pengawasan pemasangan label. Pelepasan varietas tanaman pangan diatur melalui pasal 12 ayat 2 UU 12/1992 yang menyatakan bahwa varietas hasil pemuliaan atau introduksi yang belum dilepas dilarang diedarkan. Ditegaskan dalam pasal 21 PP 44/1995 bahwa Benih dari varietas unggul hanya dapat diedarkan setelah dilepas oleh Menteri.

Penangkar benih membantu memproduksi calon benih bagi produsen. Penangkar yang mampu menjadi produsen berperan memproduksi benih yang calon benihnya diproduksi sendiri maupun oleh penangkar lainnya. Produsen benih padi dapat bermitra dengan penangkar dalam memproduksi benih. Penangkar harus mengikuti peraturan BPSB selama memproduksi calon benih di lapang hingga panen. Pada pasca panen, calon benih diproses oleh produsen hingga pengemasan dan pelabelan sesuai peraturan yang ada dibawah pengawasan BPSBTPH. Penangkar benih padi peserta Program MKMB dalam kondisi normal dapat memperoleh keuntungan Rp34 juta hingga Rp38 juta per hektar per musim atau jauh lebih tinggi dari keuntungan menanam padi untuk konsumsi, yaitu sekitar Rp16 juta per hektar per musim.

\subsection{Efektivitas Mekanisme Kontrol Mutu dan Penyaluran Benih}

Mutu benih padi dikontrol oleh BPSBTPH sejak penyiapan lahan untuk budidaya calon benih. Uji lapangan untuk lahan calon benih tanaman pangan dilakukan empat kali, yaitu pendahuluan (sebelum tanam), fase vegetatif (pertumbuhan), fase bunga, dan fase masak. Jika calon benih lulus tahap uji lapang selanjutnya akan dilakukan pemeriksaan berikutnya. Jika calon benih tidak lulus salah satu uji lapang tidak akan diuji di laboratorium. Semua tahapan diikuti oleh kelompok petani penangkar benih padi peserta Program MKMB.

Pemeriksaaan alat panen, pengolahan dan gudang dilakukan setelah selesai uji lapang. Berikutnya akan dilakukan pengambilan sampel calon benih padi untuk pengujian laboratorium. Jika tidak lulus uji maka calon benih tersebut tidak bisa diuji selanjutnya dan disarankan untuk dijual sebagai gabah konsumsi. Setelah lulus uji laboratorium, produsen benih tersebut mendapat sertifikat benih bina. Tahap selanjutnya adalah legalisasi label benih. BPSBTPH mengawasi pemasangan benih label sesuai jumlah yang didaftarkan. Berikutnya produsen memasarkan benihnya sesuai dengan masa berlaku yang tertera di label. Dalam hal ini semua kelompok penangkar benih padi yang mengikuti program MKBM dibina oleh BPSB sejak budidaya di lapang hingga pelabelan. 


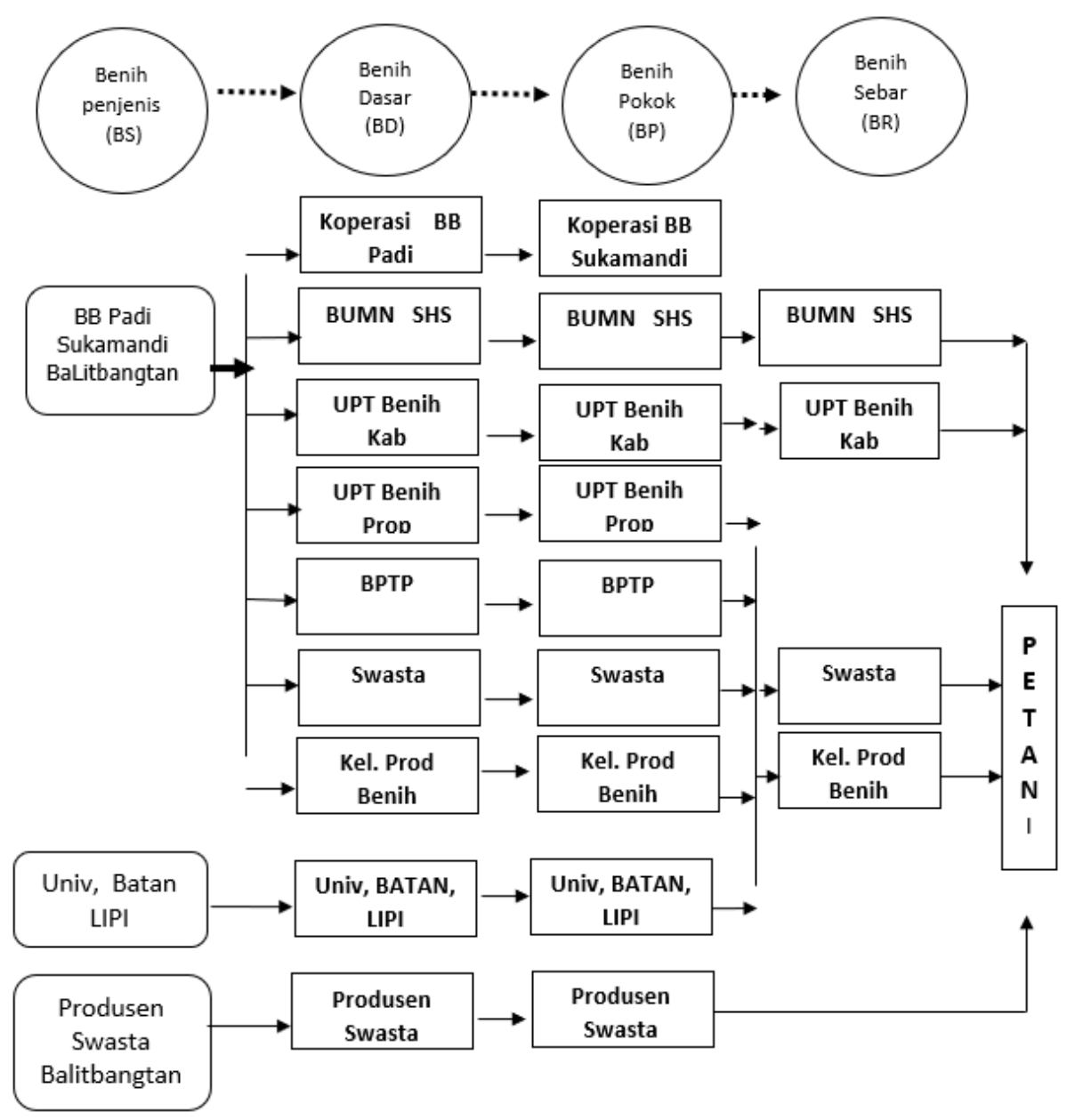

Gambar 2: Sistem Penyaluran Benih Padi Era Otonomi Daerah

Benih yang sudah dipasarkan diawasi oleh petugas BPSBTPH, yaitu Pengawas Benih Tanaman (PBT). Seharusnya secara rutin PBT mengambil sampel benih untuk diuji sebelum tanggal kadaluwarsa. Jika ada sampel benih yang tidak memenuhi syarat lagi seperti yang tertera pada label maka benih harus ditarik dari peredaran. Benih yang sudah kadaluwarsa harus diuji ulang untuk menentukan apak dapat memperoleh pelabelan ulang atau tidak.

Di berbagai provinsi menunjukkan bahwa tidak semua calon benih di lapang lulus tahap uji oleh BPSB. Umumnya dari uji di lapang, calon benih yang lolos uji berkisar dari 50-95 persen. Untuk uji laboratorium, calon benih yang lulus uji mencapai sekitar 80 persen atau lebih. Di Jawa Timur pada tahun 2014 yang lalu 
dari total jumlah calon benih padi yang diajukan untuk disertifikasi sebanyak $1.918,90$ ton dapat lulus menjadi benih sebanyak 1.802,05 ton atau sekitar 93,93 persen. Calon benih dan benih yang dimaksud adalah total benih baik jenis BS dan BD. Persentase kelulusan uji benih padi di Nusa Tenggara Barat lebih tinggi lagi di tahun yang sama, yaitu mencapai 96,29 persen. Untuk Provinsi Kalimantan Selatan, persentase kelulusan uji agak rendah karena tingginya hujan dan masih kurangnya alat pengering dan pengolah benih sehingga kadar air benih tinggi dan banyak busuk, penyiapan lahan dan pengemasan yang terlambat, dan keterjaminan pasar yaitu harga jual yang menguntungkan bagi penangkar benih, terjangkau oleh petani padi sebagai konsumen, dan permintaan yang relatif stabil. Penangkar benih padi jika bisa memasarkan produknya akan memperoleh keuntungan yang memadai seperti hasil penelitian oleh Manurung (2017) di Kabupaten Simalungun, Sumatera Utara. Penelitian lain juga menunjukkan keuntungan memadai oleh produsen maupun penangkar benih padi (Kusnadi et al., 2017; Mita et al., 2018; Fadhla \& Al Hamidi, 2019). Secara umum penangkar benih peserta MKMB mendapat keuntungan memadai kecuali di Kabupaten Maros, Sulawesi Selatan, yang hasilnya dijual sebagai calon benih atau belum disertifikasi oleh BPSBTPH. Produsen benih yang membeli calon benih padi tersebut yang mengajukan sertifikasi ke BPSBTPH di Sulawesi Selatan (Tabel 1).

Tabel 1: Biaya Produksi Benih Padi oleh Penangkar Peserta MKMB, 2015

\begin{tabular}{|c|c|c|c|c|c|}
\hline \multicolumn{2}{|c|}{ Lokasi } & \multirow{2}{*}{$\begin{array}{c}\text { Produktivitas } \\
(\mathrm{kg} / \mathrm{ha})\end{array}$} & \multirow{2}{*}{$\begin{array}{c}\text { Biaya } \\
(\mathrm{Rp} / \mathrm{kg})\end{array}$} & \multirow{2}{*}{$\begin{array}{c}\text { Harga jual } \\
\text { (Rp/kg) }\end{array}$} & \multirow{2}{*}{$\begin{array}{c}\text { Keuntungan } \\
(\mathrm{Rp} / \mathrm{kg})\end{array}$} \\
\hline Kabupaten & Provinsi & & & & \\
\hline Lombok Barat & Nusa Tenggara Barat & 3.500 & 1.593 & 8.000 & 6.407 \\
\hline $\left.\operatorname{Maros}^{*}\right)$ & Sulawesi Selatan & 5.750 & 1.241 & 3.500 & 2.259 \\
\hline Cianjur & Jawa Barat & 5.000 & 2.734 & 8.500 & 5.766 \\
\hline Tulung Agung & Jawa Timur & 6.480 & 1.490 & 6.250 & 4.760 \\
\hline Tapin & Kalimantan Selatan & 6.400 & 1.381 & 7.000 & 5.619 \\
\hline Lampung Selatan & Lampung & 2.400 & 2.421 & 6.500 & 4.079 \\
\hline
\end{tabular}

Sumber: data primer

Keterangan: Penangkar benih padi di Kabupaten Maros menjual calon benih padi (bukan benih padi bersertifikat) kepada produsen benih padi BUMN.

Di Kalimantan Selatan misalnya, untuk benih padi tahun 2014, kegiatan pengecekan mutu benih dilaksanakan untuk 14 unit kelompok benih dengan hasil 12 kelompok benih sesuai standar dan hanya 2 kelompok benih yang tidak sesuai, atau sebanyak 31.975 ton benih padi yang sesuai standar dan 0,775 ton yang tidak sesuai. Persentase benih padi yang tidak sesuai standar sangat kecil. Jumlah volume benih yang dicek tahun 2014 ini bila dibandingkan dengan tahun sebelumnya, termasuk relatif kecil karena pada tahun 2013 jumlah volume benih padi yang dicek mencapai 377.928 ton. Hal ini terutama diakibatkan oleh realisasi penyaluran benih padi juga menurun drastis dari hanya 2.584 .133 ton pada tahun 2014 dibandingkan dengan 5.369.009 ton yang berhasil disalurkan tahun sebelumnya, atau hanya sekitar 48,13 persen.

Kegiatan selanjutnya yaitu pelabelan ulang, di Kalimantan Selatan, benih padi yang masih sesuai standar relatif baik tapi perlu ditingkatkan lebih tinggi 
lagi. Dari 84 kelompok benih padi yang diperiksa untuk pelabelan ulang dan volume total sebanyak 128.241 ton, hasilnya hanya 55 kelompok benih atau sekitar 65,5 persen yang masih sesuai standar. Dari volume benih, hanya 62.305 ton saja yang masih sesuai standar atau sekitar 48,6 persen.

Di Jawa Timur, produksi sekaligus peredaran benih padi mencapai total sekitar 61.570 ton pada tahun 2014, yang didominasi oleh benih padi non-hibrida sekitar $60.789,10$ ton dan hanya sekitra 870.46 ton benih padi hibrida. Dari varietas padi non-hibrida yang beredar di Jawa Timur, varietas Ciherang masih yang paling dominan, yaitu sekitar 26.074,23 ton, jauh di atas varietas lain, seperti Situ Bagendit yang hanya sekitar 6.410.01 ton dan IR-64 sekitar 6.246,10 ton. Sementara varietas padi hibrida peredarannya sangat tergantung dan ditentukan oleh pelaksanaan program, baik pemerintah pusat maupun daerah (provinsi dan kabupaten). Sampai tahun 2012, peredaran varietas Sembada 83 sangat besar di Jawa Timur, mencapai $6.187,10$ ton, tetapi terhenti mulai tahun 2013 yang lalu. Mulai tahun 2013, varietas yang banyak beredar adalah H-546, Sembada-168, serta Sembada-169.

Hasil monitoring peredaran benih padi juga menunjukkan bahwa dari 45 jenis varietas yang diedarkan, varietas terbanyak adalah varietas Ciherang, Mekongga, Cibogo, Inpari 8 dan Inpari 2. Varietas-varietas ini jumlahnya masing-masing sekitar 1,169.995 ton; 799,680 ton; $131.170 ; 84.640$ ton dan 81.405 ton. Untuk kondisi di Provinsi Jawa Timur, kondisi peredaran benih padi untuk varietas Ciherang mirip dominasinya, sedangkan varietas lainnya agak berbeda karena varietas lainnya yang dominan adalah IR-64, Situ Bagendit, Cibogo dan Mekongga untuk padi non-hibrida serta Sembada 169 dan Sembada 168 untuk padi hibrida.

Kegiatan akhir dalam pengawasan mutu dan peredaran benih adalah pembinaan produsen dan pedagang benih, sebagaimana diatur dalam Permentan No. 2 Tahun 2014 yang menyatakan bahwa izin dan tanda daftar untuk produsen dan pedagang/pengedar benih diberikan oleh Bupati/Walikota, dan salah satu persyaratan untuk memperoleh tanda daftar/izin produksi dan peredaran benih adalah rekomendasi sebagai produsen/pengedar benih yang dikeluarkan oleh BPSBTPH. Tetapi BPSBTPH Kalimantan Selatan tahun 2014 belum mengeluarkan rekomendasi sesuai Permentan tersebut diatas karena petunjuk/pedoman tentang pengawasan peredaran dan mekanisme pemberian rekomendasi belum diterbitkan oleh pemerintah pusat. Jadi sementara untuk tahun-tahun sebelum ini tanda daftar yang diterbitkan oleh BPSBTPH adalah berdasarkan pelimpahan dari kabupaten, yaitu Kabupaten Tabalong, Hulu Sungai Utara, Hulu Sungai Tengah, Hulu Sungai Selatan, Tapin, Tanah Laut, dan Tanah Bumbu.

Pada tahun 2012 dan 2013 BPSBTPH Kalimantan Selatan menerbitkan izin sebanyak 112 produsen/pengedar dan 1 tanda daftar oleh Dinas Pertanian Kabupatan Banjar. Total produsen/pengedar yang mendapat tanda daftar ini baru sebagian saja dari sekitar 283 produsen/pengedar yang terinventarisai di seluruh provinsi Kalimantan Selatan. Atau masih kurang dari setengah potensi produsen/pengedar yang ada. Kabupaten dengan produsen/pengedar yang memiliki tanda daftar terbanyak antara lain Kabupaten Hulu Sungai Tengah, Balangan, 
Tapin, Tabalong, Banjar, dan Hulu Sungai Selatan.

Berdasarkan kegiatan klasifikasi produsen dan pedagang/pengedar benih pada tahun 2014 di 10 kabupaten menunjukkan bahwa dari 67 produsen/pedagang/ pengedar benih yang disurvei, sebagian besar adalah kelas B dan C, yaitu masingmasing sebanyak 29 dan 25 produsen/pedagang/pengedar. Sedangkan kelas A hanya 9 orang dan kelas D hanya 4 orang. Data di Provinsi Lampung juga hampir mirip kondisi dan jumlah produsen benihnya, yaitu total sekitar 297 produsen. Hanya saja, di Provinsi Lampung hampir seluruhnya adalah produsen dengan klasifikasi kecil, dan hanya 1 produsen yang dapat diklasifikasikan sebagai produsen menengah.

Berdasarkan gambaran dan analisis kegiatan-kegiatan terkait pengawasan mutu dan perederan benih padi hasil pengamatan seperti berikut ini. Pengawasan peredaran benih di pasar masih kurang optimal. Sebagian BPSB melakukan pemeriksaan rutin sekali dalam satu musim terhadap sebagian besar kios penjual benih yang dilakukan oleh PBT. Walaupun demikian ada juga kios benih di sebagian provinsi yang tidak pernah diperiksa oleh PBT. Alasan kurangnya pengawasan terhadap peredaran benih komersial adalah karena jumlah PBT di BPSBTPH yang relatif terbatas.

Terdapat berbagai peluang dalam produksi, pengawasan, dan penyaluran benih bersertifikat. Peluang tersebut antara lain: (a) banyak dilepas varietas unggul baru oleh Menteri Pertanian; (b) tersedianya Benih Penjenis Padi oleh Balitpa Sukamandi; (c) dukungan sosialisasi varietas unggul baru oleh BPTP; (d) tersedianya laboratorium pengujian yang representatif; (e) dukungan tenaga/petugas Fungsional PBT; (f) tersedianya lahan produksi yang cukup baik milik produsen dan Balai Benih; (g) jumlah produsen yang cukup di tiap provinsi, dan (h) dukungan kebijakan pemerintah daerah. Peluang ini dapat mendorong makin tumbuh berkembangnya para penangkar dan produsen benih padi bersertifikat.

Faktor lain yang perlu mendapat prioritas dalam pengembangan MKMB adalah harga benih yang menarik bagi penangkar, permintaan pasar yang relatif dapat diperkirakan, dan proses administrasi yang terjangkau, cepat, dan andal. Hambatan yang dihadapi dalam produksi, pengawasan, dan penyaluran benih bersertifikat adalah: (a) keterbatasan alat prosesing benih terutama perontok dan dryer; (b) jaminan pasar bagi calon benih/benih yang tidak jelas, akibatnya banyak calon benih/benih dijual untuk konsumsi; (c) terbatasnya jumlah PBT tidak sebanding dengan luas wilayah kerja; (e) prasarana pengujian, yaitu green house kurang memadai; (f) terbatasnya jumlah Analis di Laboratorium; dan (g) tidak ada contoh benih yang otentik dari varietas yang baru dilepas. Permasalahan tersebut umum dijumpai di Kalimantan Selatan dan Jawa Timur.

Peraturan yang paling sering dilanggar oleh penangkar benih antara lain waktu mengajukan sertifikasi. Penangkar harus mengajukan 10 hari sebelum semai, tetapi masih ada penangkar yang mengajukan terlambat satu bulan karena respon kedatangan PBT yang masih tertunda karena berbagai hal. Waktu keterlambatan bisa bertambah kalau petugas pengawasnya kurang kreatif. Ada juga penangkar yang tidak mau melakukan sertifikasi karena masalah waktu 
yang dirasa cukup lama dan permintaan konsumen yang mendesak. Lama terbit sertifikasi benih padi ini perlu mendapat prioritas pembenahan dan penyelesaian. Benih padi impor, misalnya benih padi hibrida, jika dipasarkan tetap diawasi oleh BPSBTPH. Umumnya benih padi hibrida jarang dijual melalui mekanisme pasar terbuka, tetapi merupakan benih bersubsidi yang diedarkan secara tertutup untuk kelompok tani tertentu di beberepa provinsi.

Keluhan petani yang diterima BPSBTPH untuk benih padi bersertifikat yang beredar di pasar antara lain daya tumbuh benih yang relatif rendah dan kotoran benih cukup banyak. Kondisi ini secara umum dialami para petani di Provinsi Jawa Timur, Kalimantan Selatan, Jawa Barat, Lampung, dan Nusa Tenggara Barat. Di Provinsi Jawa Timur dan Jawa Barat, hal ini sudah tidak terlalu dominan dan dapat dengan segera diatasi dengan penggantian benih baru dan pelabelan ulang oleh produsen. Sementara di tingkat pengecer, keluhan yang disampaikan ialah adanya campuran varietas lain relatif banyak dalam kemasan yang dipergunakan. Pengecer dan pedagang besar di Lampung, Kalimantan Selatan dan Nusa Tenggara Barat masih sering juga mengalami hambatan kekurangan ketersediaan varietas benih bersertifikat yang diminati petani misalnya Inpari. Khusus untuk pengecer dan pedagang besar masih banyak ditemukan dan dilaporkan pemalsuan benih bersertifikat. Kondisi pemalsuan benih bersertifikat ini masih berlangsung di semua provinsi lokasi contoh, walaupun intensitas, frekuensi, dan volumenya berbeda-beda antara provinsi dan antar kabupaten. Makin maju dan intensif penggunaan benih bersertifikat suatu sentra produksi, maka relatif semakin tinggi frekuensi dan volume peredaran benih bersertifikat palsu, seperti di Jawa Timur, Jawa Barat, dan Lampung.

\subsection{Faktor-Faktor yang Memengaruhi Tingkat Adopsi}

Produsen benih, termasuk penangkar benih, selalu berusaha mengadopsi teknologi produksi benih untuk memperoleh hasil terbaik agar benih laku dijual dengan harga memadai. Demikian pula petani akan menanam benih unggul berkualitas baik agar memperoleh hasil tertinggi. Walaupun demikian produsen benih maupun petani menghadapi berbagai faktor sehingga adopsi tidak bisa optimal.

Produsen benih padi umumnya memproduksi benih sesuai dengan permintaan atau pasar yang selama ini ada. Varietas benih padi yang diproduksi disesuaikan dengan pilihan atau preferensi petani. Selera petani terhadap varietas dapat berubah seiring dengan daya tahan varietas tersebut terhadap serangan hama dan penyakit maupun perubahan iklim, yaitu daya tahan varietas terhadap kekeringan dan cuaca basah (kelembaban udara yang tinggi). Pada taraf tertentu sulit menemukan varietas yang produktivitasnya lebih tinggi dari varietas yang sudah ada. Petani bersedia mengadopsi benih padi varetas unggul antara lain dipengaruhi oleh ketersediaan benih, harga benih, kualitas beras, dan produktivitas varietas (Masyitah et al., 2019).

Produsen benih di pedalaman, misalnya di Pulau Sumbawa, Nusa Tenggara 
Barat, kesulitan mencari mencari benih sumber, yaitu kelas benih BD atau BP, di sekitar lokasi penangkaran untuk menghasilkan benih kelas BR. Mereka harus membeli benih ke Mataram. Masalah lain yang dihadapi produsen adalah pengeringan benih. Pada $\mathrm{MH}$ produsen atau penangkar sulit menjemur gabah calon benih agar bisa mencapai kadar air maksimum 14 persen. Banyak penangkar yang belum mempunyai alat pengering atau lantai jemur dengan kanopi sehingga mempermudah penjemuran selama MH. Produsen benih di NTB, misalnya, merasa mendapat saingan dari BBI karena BBI selain memproduksi benih sumber juga memproduksi benih komersial untuk keperluan petani.

Petani padi umumnya menyukai suatu varietas dengan karakteristik tertentu, yaitu: (a) produktivitas tinggi; (b) varietas tersebut lebih tahan hama penyakit dibandingkan varietas lainnya; (c) rasa nasi yang pulen, tetapi di beberapa daerah rasa nasi yang enak belum tentu yang pulen seperti di Kalimantan dan Sumatera; dan (d) pemasaran hasil mudah atau pedagang menyukai beras dari varietas tersebut. Faktor lain yang mempengaruhi preferensi petani untuk mengadopsi adalah mudah diperoleh dan harganya terjangkau.

Bantuan benih (BR) gratis maupun subsidi benih secara umum menekan produksi benih oleh penangkar swasta. Produsen swasta sulit untuk berperan serta dalam menghasilkan benih berkualitas dengan harga layak. Juga ada kelemahan benih bantuan (gratis), yaitu berkualitas rendah, antara lain banyak kotoran atau gabah hampa, serta daya tumbuh rendah atau tidak sesuai dengan informasi yang tertera pada label benih. Banyak petani yang tidak menanam benih bantuan tersebut dan menggunakan benih sendiri atau membeli benih yang kualitasnya lebih baik. Citra benih BR juga semakin kurang baik sehingga banyak petani padi memilih menanam benih BP dengan anggapan hasilnya lebih baik, bisa ditanam sekali untuk musim tanam berikutnya, dan harganya hanya sedikit lebih mahal dibanding BR.

BBI kesulitan menjual benih dasar (BD) yang dihasilkan karena saat ini BB Padi dan UPBS BPTP juga menghasilkan BD. Sementara itu BP yang dihasilkan oleh BBU juga semakin sulit terjual karena banyak produsen swasta yang mampu menghasilkan BP karena bisa membeli BS maupun BD ke Balit maupun BPTP. Perlu dipertimbangkan lagi keberadaan BBI dan UPBS. Umumnya BBI tidak lagi bisa menggunakan seluruh lahan sawah yang dimilikinya secara optimal untuk memproduksi benih padi. Misalnya, dari 12 ha lahan BBI Provinsi Lampung di Kabupaten Lampung Selatan hanya 2 ha yang diusahakan untuk produksi benih padi, selebihnya hanya untuk budidaya padi yang menghasilkan gabah untuk konsumsi. Lebih dari 200 ha lahan BBI Provinsi Jawa Barat disewakan kepada para petani di sekitarnya untuk usahatani maupun porduksi benih padi.

BPTP perlu mendorong penangkar di daerah, termasuk peserta Program $\mathrm{MKMB}$, dimana penggunaan benih bersertifikat relatif rendah untuk menghasilkan benih bermutu, yaitu tanpa sertifikat, sampai pemeriksaan lapang ketiga oleh BPSB, dan tidak harus uji laboratorium. Hal ini untuk memenuhi kebutuhan benih petani di sekitarnya dengan cara ditukar (barter).

Agar kebijakan tentang kelembagaan perbenihan dapat diimplementasik- 
an di lapang secara berkelanjutan, kebijakan tentang kelembagaan hendaknya berorientasi kepada pemenuhan kebutuhan dan atau pemecahan masalah yang dihadapi oleh petani sebagai pengguna akhir dari benih yang diproduksi. Dalam analisis kebijakan tentang kelembagaan perbenihan ini akan dimulai dari kajian tentang kebutuhan petani terhadap benih, yang ternyata beragam sesuai dengan kondisi social ekonomi rumah tangga petani dan komunitas dimana petani tinggal, serta kondisi kondisi agro ekosistem di mana usaha tani tersebut dilaksanakan oleh petani.

Karakteristik respons petani terhadap penggunaan benih unggul adalah: (i) beragamnya pemahaman petani tentang benih bermutu untuk meningkatkan produkstivitas usaha tani padi; (ii) beragamnya tingkat adopsi petani terhadap intoduksi benih baru yang sangat ditentukan oleh preferensi petani terhadap kualitas beras yang dihasilkan dan atau preferensi pedagang gabah atau beras; (iii) kondisi cekaman lingkungan yang dihadapi petani, sehingga petani membutuhkan varietas tanaman sesuai; (iv) petani berlahan sempit dan tidak cukup modal untuk membeli benih unggul bersertifikat yang harganya relatif mahal; dan (vi) kearifan lokal petani yang secara turun temurun sudah dimiliki oleh petani di suatu komunitas tentang benih yang sesuai dengan kondisi lokal spesifik masyarakat setempat.

\section{Simpulan dan Saran}

Kebijakan perbenihan tanaman pangan, khususnya benih padi, saat ini sudah memadai. Kebijakan tersebut ditujukan agar para produsen benih padi menghasilkan benih dengan kualitas baik. Produsen dan penangkar benih mampu memproduksi benih lebih banyak jika iklim usaha menguntungkan. Jaminan pasar merupakan pertimbangan utama bagi produsen dan penangkar untuk menentukan volume dan varietas benih yang akan diproduksi. Insentif perlu diberikan kepada produsen dan penangkar, misalnya akses modal yang lebih mudah dan bunga bank lebih murah, bantuan promosi produk atau pembelian benih langsung oleh pemerintah untuk progam bantuan dan subsidi yang bukan hanya diberikan kepada produsen BUMN.

Pengawasan atau kontrol yang dilakukan oleh BPSB TPH terhadap produksi dan peredaran benih bina relatif baik. Penangkar benih padi juga memperoleh keuntungan yang memadai. Walaupun demikian pengawasan oleh BPSBTPH kepada penangkar dan produsen benih tetap harus dilakukan agar proses produksi benih sesuai dengan standar yang telah ditentukan. Pengawasan peredaran benih terhadap pedagang juga tetap perlu dilakukan agar benih yang beredar berkualitas, tidak kadaluwarsa, dan label yang tertera pada kemasan sesuai dengan karakter benih yang diperdagangkan.

Penangkar bersedia menanam benih varietas unggul jika benih sumber tersedia. Harga benih sumber harus relatif terjangkau dan produktivitas tinggi. Petani bersedia menanam benih bermutu dari varietas unggul jika harganya terjangkau, mudah diakses, dan sesuai dengan lingkungan setempat. Bimbingan dari BPSB 
TPH sangat diperlukan agar penangkar dapat menghasilkan benih berkualitas. Kelembagaan perbenihan perlu ditinjau ulang dengan adanya UPBS BPTP dan BB Padi yang menghasilkan benih dasar. Hal ini ditambah dengan kemudahan akses terhadap BS oleh produsen benih ke BB Padi. Penangkar benih padi sebaiknya diperbolehkan menjual benih berkualitas tanpa sertifikat kepada petani padi di sekitarnya yang masih masih mengadopsi sistem perbenihan informal tetapi prosesnya tetap diawasi oleh BPSBTPH, menjual calon benih lulus uji lapang kepada produsen benih, atau bermitra dengan kios saprodi setempat dalam memasarkan benih berlabel. Pembinaan penangkar benih padi lebih efektif dilakukan di daerah dimana produksi dan penjualan benih padi bersertifikat masih sedikit seperti di Nusa Tenggara Barat.

\section{Ucapan Terima Kasih}

Penulis mengucapkan terima kasih kepada Prof. Dr. Nyoman Widiarta (Pusat Penelitian dan Pengembangan Tanaman Pangan), Dr. I Ketut Karyasa, Dr. Hermanto, dan Valeriana Darwis, S.E., M.M. (Pusat Sosial Ekonomi dan Kebijakan Pertanian) sehingga penelitian bisa terlaksana dengan baik.

\section{Daftar Pustaka}

[1] Badan Litbang Pertanian. (2015). Pedoman Umum Pengembangan Model Kawasan Mandiri Benih Padi, Jagung, Kedelai. Jakarta: Badan Penelitian dan Pengembangan Pertanian.

[2] Baglan, M., Mwalupaso, G. E., Zhou, X., \& Xianhui, G. (2020). Towards cleaner production: Certified seed adoption and its effect on technical efficiency. Sustainability, 12(4), 1344. doi: https:/ / doi.org/10.3390/su12041344.

[3] Bastari, T. (1995). Seed production and marketing in Asia Pacific. Country Paper: Indonesia (2). Report of an APO Seminar, September 14-23, 1993, Jakarta. Asian Productivity Organization. Tokyo, pp. 210-232.

[4] BBN. (2004). Strategi umum pembangunan perbenihan nasional. Jakarta: Badan Benih Nasional Departemen Pertanian.

[5] Bishaw, Z., Struik, P. C., \& Van Gastel, A. J. G. (2012). Farmers' seed sources and seed quality: 1. physical and physiological quality. Journal of Crop Improvement, 26(5), 655-692. doi: https://doi.org/10.1080/15427528.2012.670695.

[6] Direktorat Perbenihan. (2014). Subsidi benih TA 2014. Bahan Presentasi dalam acara Rapat dengan Bappenas, 8 Juli 2014, Jakarta.

[7] Douglas, J. E. (1980). Successful seed programs. Westview. International Agricultural Development Series. Colorado.

[8] El Khoury, W., \& Delve, R. (2018). Lesson learned: Supporting smallholder seed systems: Agronomy. Rome: International Fund for Agricultural Development (IFAD) Policy and Technical Advisory Division. https://www.ifad.org/documents/38714170/ 40250597/Seeds_LL.pdf/dd9f46b3-4f26-48a3-9f94-3f09cd126cb9.

[9] Fadhla, T. \& Al Hamidi, A. (2019). Studi usaha tani pada kelayakan pembenihan padi varietas Ciherang di Kecamatan Meureudu Kabupaten Pidie Jaya. Jurnal Agriflora, $3(1), 67-76$. 
[10] Fitri, M. A., Afrizal, R., \& Yuliandri, Y. (2018). Analisis Sistem Kemitraan Petani Penangkar dan PT. Pertani dengan PT. Citra Nusantara Mandiri. Journal of Agribusiness and Community Empowerment, 1(1), 28-37. doi: https://doi.org/10.32530/jace.v1i1.25.

[11] Ilyas, S., Surahman, M., Suwarto, Sujiprihati, S., Hidayat, Y. R., \& Wijono, A. (2008). Evaluasi Kinerja Sistem Perbenihan. Prosiding Seminar Nasional dan Workshop Perbenihan dan Kelembagaan: Peran Perbenihan dan Kelembagaan dalam Memperkokoh Ketahanan Pangan, Yogyakarta, 10-11 November 2008, pp. 32-43. Fakultas Pertanian Universitas Pembangunan Nasional "Veteran" Yogyakarta dan Forum Perbenihan Komda DIY. http:/ / repository.ipb.ac.id/jspui/bitstream/123456789/56183/1/ Memen\%20s\%20-\%20Prosiding\%20Perbenihan\%20dan\%20Lembaga.pdf.

[12] Kementerian Hukum dan Hak Asasi Manusia. (2014). Peraturan Menteri Pertanian Republik Indonesia Nomor 02/Permentan/SR.120/1/2014 Tentang Produksi, Sertifikasi, dan Peredaran Benih Bina. Jakarta.

[13] Kementerian Pertanian. (2010). Rencana Strategis Kementerian Pertanian Tahun 20102014.

[14] Kusnadi, D., Sujaya, D. H., \& Noormansyah, Z. (2017). Analisis usahatani penangkaran benih padi (Oryza Sativa L.) varietas Ciherang. Jurnal Ilmiah Mahasiswa AGROINFO GALUH, 1(2), 89-96. doi: http:/ /dx.doi.org/10.25157/jimag.v1i2.242.

[15] Manurung, D. S. L. (2017). Analisis pendapatan petani penangkar benih padi (Oryza sativa L.) di Kabupaten Simalungun (Tesis, Program Studi Magister Agribisnis Universitas Medan Arena).

[16] Masyitah, M., Agussabti, A., \& Kasimin, S. (2019). Tingkat adopsi petani terhadap benih unggul padi sawah di Kabupaten Aceh Besar Provinsi Aceh. Agrifo: Jurnal Agribisnis Universitas Malikussaleh, 4(1), 27-32. doi: https://doi.org/10.29103/ag.v4i1.1538.

[17] Mita, Y. T., Haryono, D., \& Marlina, L. (2018). Analisis pendapatan dan faktorfaktor yang mempengaruhi pengambilan keputusan usahatani penangkaran benih padi di Kabupaten Pesawaran. Jurnal Ilmu-Ilmu Agribisnis, 6(2), 125-132. doi: http://dx.doi.org/10.23960/jiia.v6i2.\%25p.

[18] Nugraha, U. S. (2004). Legislasi, kebijakan, dan kelembagaan pembangunan perbenihan. Perkembangan Teknologi TRO, 16(1), 13.

[19] Nugraha, U. S., Wahyuni, S., Samaullah, M. Y., \& Ruskandar, A. (2009). Sistem perbenihan padi. pp. 91-122. Subang: Balai Besar Penelitian Tanaman Padi. http: //www.litbang.pertanian.go.id/special/padi/bbpadi_2009_itp_04.pdf.

[20] Nurmanaf, A. R., Rusastra, I. W., Darwis, V., Marisa, Y., \& Situmorang, J. (2003). Evaluasi sistem distribusi benih dan pupuk dalam mendukung ketersediaan dan stabilitas harga di tingkat petani. Pusat Penelitian Sosial Ekonomi Pertanian. Bogor.

[21] Paturohman, E., \& Sumarno, S. (2017). Sistem perbenihan formal dan informal tanaman pangan. Iptek Tanaman Pangan, 12(2), 75-82.

[22] Ruskandar, A., Wahyuni, S., Mulya, S. H., Rustiati, T., \& Balai Besar Penelitian Tanaman Padi. (2007). Respon petani di Pulau Jawa terhadap benih bersertifikat. Apresiasi hasil penelitian padi 2007, pp. 881-888. Bogor (ID): Balai Besar Penelitian Tanaman Padi Sukamandi. http://www.litbang.pertanian.go.id/special/padi/ bbpadi_2008_p2bn2_28.pdf.

[23] Sayaka, B., \& Hidayat, D. (2015). Sistem perbenihan padi dan karakteristik produsen benih padi di Jawa Timur. Analisis Kebijakan Pertanian, 13(2), 185-202. doi: http:/ /dx.doi.org/10.21082/akp.v13n2.2015.185-202.

[24] Singh, R. P., \& Agrawal, R. C. (2018). Improving efficiency of seed system by appropriating farmer's rights in India through adoption and implementation of policy of 
quality declared seed schemes in parallel. MOJ Ecology \& Environmental Sciences, 3(6), 387-391.

[25] Soemardhi. (1987). Indonesia's cereal seed industry: An overview. In Cereal seed industry in Asia and the Pacific, pp. 187-207. Asian Productivity Unit, Tokyo.

[26] Sperling, L., Boettiger, S., \& Barker, I. (2013). Integrating seed systems. Planning for Scale Brief \#3. https://seedsystem.org/wp-content/uploads/2014/03/ Integrating-Seed-Systems-.pdf.

[27] Ulpah, A., Tinaprilla, N., \& Baga, L. M. (2018). Analisis efisiensi teknis usahatani penangkaran benih padi pola kemitraan di Kabupaten Subang: Pendekatan Stochastic Frontier Analysis. Jurnal Pengkajian dan Pengembangan Teknologi Pertanian, 21(3), 259-275. doi: http://dx.doi.org/10.21082/jpptp.v21n3.2018.p259-275.

[28] Widiarta, I. N. (2017). Sekolah Lapang (SL) kedaulatan pangan yang mendukung swasembada pangan terintegrasi desa mandiri benih padi, jagung, kedelai (Laporan Akhir, Pusat Penelitian dan Pengembangan Tanaman Pangan, Badan Penelitian dan Pengembangan Pertanian, Kementerian Pertanian).

[29] Widiarta, I. N. (2018). Sekolah Lapang (SL) kedaulatan pangan yang mendukung swasembada pangan terintegrasi desa mandiri benih padi, jagung, kedelai (Laporan Akhir, Pusat Penelitian dan Pengembangan Tanaman Pangan, Badan Penelitian dan Pengembangan Pertanian, Kementerian Pertanian).

[30] Widiarta, I. N. (2019). Sekolah Lapang (SL) kedaulatan pangan yang mendukung swasembada pangan terintegrasi desa mandiri benih padi, jagung, kedelai (Laporan Akhir, Pusat Penelitian dan Pengembangan Tanaman Pangan, Badan Penelitian dan Pengembangan Pertanian, Kementerian Pertanian). 
this page intentionally left blank 